\title{
Enhancing Yield, Quality and Profitability of Sugar Beet Combining Potassium Fertilizer and Application Date of Yeast
}

\author{
H. Ferweez and A. M. Abd El-Monem** \\ Food Sci. \& Techn. Dept. and *Agron. Dept., Fac. Agric. New Valley Branch, Assiut \\ Univ., New Valley, Egypt.
}

\begin{abstract}
OOD fertilizer management is critical for high yielding, quality and profitability of sugar beet. This work was carried out at Mallawi Agric. Res., Station, El-Minia Governorate, Egypt, during 2012/2013 and 2013/2014 seasons to study effect of three application dates of yeast, i.e., 80, 110 and 140 days of sowing and three levels of potassium fertilizer, i.e., 0, 24, $48 \mathrm{~kg} \mathrm{~K}_{2} \mathrm{O} /$ fad on vegetative, physiochemical, yield traits and profitability of sugar beet. A split plot design with four replications was used in both seasons and Monetbianco cultivar was sown.
\end{abstract}

The obtained results indicated that addition time of yeast or/and level of potassium fertilizer $\left(\mathrm{kg} \mathrm{K}_{2} \mathrm{O} / \mathrm{fad}\right)$ exhibited a significant effect on vegetative characters of beet roots. Physical properties of beet roots, such as SR (Sugar recovery) \%, QZ (Quality index) \% and SL (Sugar loss) \%, chemical constituents (pol (polarization) \%, K, Na and a-N determined as milliequivalent $/ 100 \mathrm{~g}$ beet), except the $2^{\text {nd }}$ season for $\mathrm{Na}$ content of beet roots not reached significant level, and productivity traits of sugar beet, i.e., roots yield and recoverable sugar yield (ton/fad) in both growing seasons and combined.

The interaction between addition time of yeast with K-fertilization level was significant on vegetative traits of sugar beet, physical properties of beet roots, chemical constituents and productivity traits of sugar beet. Yeast addition at age 80 days was markedly increased the total return per fad by 27.64 and $26.85 \%$ and net profit by 60.80 and $58.64 \%$ as well as sugar yield in ton $/ 1000 \mathrm{~m}^{3}$ by 7.14 and $0.84 \%$ compared with applying yeast at ages 110 and 140 days, respectively.

In general, it can be concluded from the results that applying yeast at age 80 days from sowing with $24 \mathrm{~kg} \mathrm{~K} 2 \mathrm{O} /$ fad could be recommended because it achieved the maximum values of SR\% (16.27\%), QZ (86.99\%) and pol \% (18.71), while it contained the lowest values of SL\% (2.44 \%) a-N (1.24 milliequivalent/100 g) and $\mathrm{Na}$ (1.31 milliequivalent/100 g) contents. While, the highest values ( 4.73 and $4.78 \mathrm{ton} / \mathrm{fad}$ ) for recoverable sugar yield of sugar beet was recorded with adding yeast at ages 80 and 140 days from sowing with $24 \mathrm{~kg} \mathrm{~K}_{2} \mathrm{O} /$ fad, respectively.

Keywords: Sugar beet, $\mathrm{K}_{2} \mathrm{O}$ level, Yeast, Quality index and pol \%.

\section{Introduction}

Sugar beet (Beta vulgaris L.)was introduced to Egypt in 1982 to overlap the vast gap between sugar consumption and production, which reached $30.50 \%$ (about 0.96 million ton) of local needs of white sugar in 2016. Sugar beet represents the first main sugar crop for sugar production before sugar cane in Egypt. About 35\% of total world sugar production and $57.62 \%$ of the total Egyptian local sugar production (2.2 million ton) in 2016 was produced from sugar beet, while sugar cane produced the rest $(42.38 \%)$. Improvement of sucrose yield in sugar beet has been a slow process. Potential root yield has been restricted, because of a negative correlation between sucrose concentration and root yield and the need to maintain an acceptable level of sucrose concentration (Ferweez et al., 2011 and CCSC, 2017).

Little information is available about the effect of application of yeasts as bio-fertilizers on the

\#Corresponding author email: abdelmonem07@gmail.com

DOI : 10.21608/agro.2018.2120.1086

(C)2018 National Information and Documentation Center (NIDOC) 
productivity and growth enhancement of sugar beet. Searching new yeasts as bio-fertilizers and studying their productivity of bioactive chemical compounds expand our knowledge about their approached mechanisms to enhance the plant growth and soil characteristics. We assume that a good understanding of the role of soil yeasts in the rhizosphere holds a key to future sustainable agricultural practices. In addition to their role in enhancing the growth of the plants, biofertilizers can act as biocontrol agents in the rhizosphere at the same time (Boraste et al., 2009). Saccharomyces cerevisiae is considered as a new promising plant growth promoting yeast for different crops. Recently, it became a positive alternative to chemical fertilizers safely used for human, animal and environment (Omran, 2000). Earlier reports explained the effect of yeast application on vegetative growth due to its richness in tryptophan which consider precursor of IAA (Indole acetic acid) and on flower ignition due to its effect on carbohydrate accumulation (Warring $\& \mid$ Philips, 1973). Agamy et al. (2013) showed that application of the yeasts significantly $(\mathrm{P}<0.05)$ increased the photosynthetic pigments, soluble sugars, sucrose, and total soluble proteins of sugar beet. It increased the sucrose content by about $43 \%$ of the control. They added that this method avoids the use of synthetic chemical fertilizers and genetically modified organisms to influence the growth of crops. Ibrahim et al. (2002) revealed that yeast significantly increased the yield of roots, leaves, sugar and sucrose content of sugar beet.

Low quality of sugar beet roots is a major problem which faces expanding of sugar beet agriculture in middle Egypt, particularly at ElMinia Governorate. Potassium is known for its role in sucrose transportation and accumulation in storage tissues of plants. Potassium (K) plays a particularly critical role in plant growth and metabolism, and it contributes greatly to the survival of plants that are under various biotic and abiotic stresses. Pol \% of beet roots was a significantly increase with increasing the potassium application rate to $24 \mathrm{~kg} \mathrm{~K} 2 \mathrm{O} /$ fad (Ferweez $\mid \&$ Abo El.Wafa, 2004). In addition, they reported that $\mathrm{K}, \mathrm{Na}$, and $\alpha-\mathrm{N}$ contents of fresh roots were increased with increasing $\mathrm{K}$ level until $48 \mathrm{~kg} \mathrm{~K}_{2} \mathrm{O} /$ fad. Fertilizers play an important role in increasing sugar beet production. Potassium plays an important role in enzyme activation, charge balance and osmoregulation in plants (Cakmak, 2005). It is assumed that $\mathrm{P}$ and $\mathrm{K}$ fertilizing increases both, yield and sugar beet quality. As a consequence, potash consumption has increased dramatically in most regions of the world (Pettigrew, 2008). $\mathrm{K}$ plays essential roles in enzyme activation, protein synthesis, photosynthesis, osmoregulation, stomatal movement, energy transfer, phloem transport, cation-anion balance and stress resistance (Marschner, 2012). He indicated that root and top yields of sugar beet increased significantly with increasing $\mathrm{K}$-fertilizer rate to $48 \mathrm{~kg} \mathrm{~K}_{2} \mathrm{O} /$ fad and its components, while, fertilizing with $36 \mathrm{~kg} \mathrm{~K}_{2} \mathrm{O}$ / fad came in the second rank (Wang et al., 2013 and Abido et al., 2015). In addition, they revealed that the highest sugar yield and sucrose $\%$ were obtained when potassium fertilizer was added by $36 \mathrm{~kg} \mathrm{~K} \mathrm{O} / \mathrm{fad}$ in both seasons. Abdelaal et al. (2015) reported that application of potassium at rate of $48 \mathrm{~kg} \mathrm{~K}_{2} \mathrm{O} /$ fad significantly increased root diameter and root fresh weight, root and sugar yields/fad as well as sucrose\%. However, Shalaby et al. (2002) indicated that the root, top and sugar yields were not affected by potassium fertilization.

Nowadays, a great attention has been focused on the possibility of using natural and safe agents such as yeast for promoting growth of sugar beet a key to future sustainable agricultural practices (Oliver et al., 2013). Chemical composition of bread yeast on dry weight basis according to Nagodawithana (1991) was, protein 47\%, nucleic acids $8 \%$, carbohydrates $33 \%$, lipids $4 \%$ and minerals $8 \%$ such as $\mathrm{Na}, \mathrm{Fe}, \mathrm{Mg}, \mathrm{K}, \mathrm{P}, \mathrm{S}, \mathrm{Zn}, \mathrm{Mn}$, $\mathrm{Cu}, \mathrm{Si}, \mathrm{Cr}, \mathrm{Ni}, \mathrm{Va}$ and $\mathrm{Li}$ in addition to thiamin, riboflavin, pyridoxine, hormones and other growth regulating substances, biotin, B12 and folic acid. In Egypt, the use of yeast as a bio-fertilizer in agriculture has taken a considerable attention, where some sugar beet growers in different regions of El-Minia Governorate use yeast application to increase sugar beet roots yield at late stage of beet age during March or April months but reduction of roots quality delivered to sugar factory was observed. So, the objective of this work was to study the effect of addition time of yeast and potassium fertilizer level on productivity traits, physiochemical parameters and profitabilityof sugar beet.

\section{$\underline{\text { Materials and Methods }}$}

The presented work was conducted at Mallawi Agric. Res., Station, Minia Governorate, Egypt, during 2012/2013 and 2013/2014 seasons to study the effect of addition time of yeast (Soil application) and level of potassium fertilizeron yield, physiochemical properties and profitability of sugar beet. 
Materials

Sugar beet

Sugar beet cultivar namely Montebianco was used.

Mineral potassium

In the form of potassiumsulphate, $48 \% \mathrm{~K}_{2} \mathrm{O}$ as soil application was added with the first dose of nitrogen fertilizer after thinning as side dressing in beet rows.

Yeast (Saccharomyces cerevisae strain, $\mathrm{SC})$ strain, active wet yeast, $(2.0 \mathrm{~kg}$ wet yeast/ fad) obtained from the Egyptian Sugar and its Integrated Industries Company, Hawamdia, Egypt, was carefully prepared before use by the accessory addition of the Egyptian treacle at $0.20 \%$ to prepared solution of yeast for activation the reproduction of yeast. Yeast solution was left stand at about $38^{\circ} \mathrm{C}$ for one hour before soil application (1 liter yeast solution/plot) at age 80, 110 and 140 days from sowing date of sugar beet after the irrigation.

\section{Field experiment}

A split plot in RCBD design with four replications was used. Sugar beet was sown on $6^{\text {th }}$ and $4^{\text {th }}$ October in both seasons $(2012 / 2013$ and 2013/2014). Three of addition times of yeast, i.e., 80,110 and 140 days from sowing date were arranged in the main plots. Meanwhile, three levels of potassium, i.e., $0.0,24,48 \mathrm{~kg} \mathrm{~K}_{2} \mathrm{O} / \mathrm{fad}$ were allocated to the sub plots. Sub plots area were $21 \mathrm{~m}^{2}$, each consisting of five, $60 \mathrm{~cm}$ wide rows, each of 7 meters long. Sugar beet was sown in hills $16 \mathrm{~cm}$ apart on rows. Nitrogen fertilizer in the form of urea $(46 \%)$ was added as a side dressing at the recommended rate of $70 \mathrm{~kg} \mathrm{~N} / \mathrm{fad}$ in two equal doses (the first one was after thinning, while the second one was added after 30 days later). Phosphorus fertilizer was added at recommended rate of $30 \mathrm{~kg} / \mathrm{fad}$ at planting. Beet plants were thinned to one plant/hill at the age of 35 days from sowing. Some chemical and physical properties of the experimental soil before soil preparation were determined according to the procedures outlined by Jackson (1967) in Table 1.

TABLE 1. Some physical and chemical characteristics of the experimental soils*.

\begin{tabular}{|c|c|c|}
\hline Properties & Season 2012/13 & Season $2013 / 14$ \\
\hline \multicolumn{3}{|l|}{ Texture analysis: } \\
\hline Clay \% & 37.30 & 38.40 \\
\hline Silt \% & 49.70 & 48. 50 \\
\hline Sand \% & 13.00 & 13. 10 \\
\hline Texture grade: & Silty Clay Loam & Silty Clay Loam \\
\hline $\mathrm{pH}(1: 2.5)$ & 8.10 & 8.00 \\
\hline $\operatorname{Ec}\left(\mathrm{dSm}^{-1}\right)(1: 2.5)$ & 1.80 & 1.70 \\
\hline Organic matter \% & 1.21 & 1.19 \\
\hline \multicolumn{3}{|l|}{ Soluble cations: } \\
\hline $\mathrm{Ca}^{++}+\mathrm{Mg}^{++} \mathrm{meq} / \mathrm{L}$ & 12.39 & 11. 48 \\
\hline $\mathrm{Na}^{+}$meq/L & 4.81 & 4.41 \\
\hline $\mathrm{K}^{+} \quad \mathrm{meq} / \mathrm{L}$ & 0.25 & 0.24 \\
\hline \multicolumn{3}{|l|}{ Soluble anions: } \\
\hline $\mathrm{CO}_{3}+\mathrm{HCO}_{3} \mathrm{meq} / \mathrm{L}$ & 3.78 & 3.39 \\
\hline $\mathrm{Cl}^{-} \quad \mathrm{meq} / \mathrm{L}$ & 5.77 & 4.84 \\
\hline Total N \% & 0.11 & 0.10 \\
\hline Available P (ppm) & 11.6 & 11.1 \\
\hline Available K (ppm) & 168 & 176 \\
\hline \multicolumn{3}{|l|}{ * Each value represents the mean of 5 samples. } \\
\hline \multicolumn{3}{|c|}{ 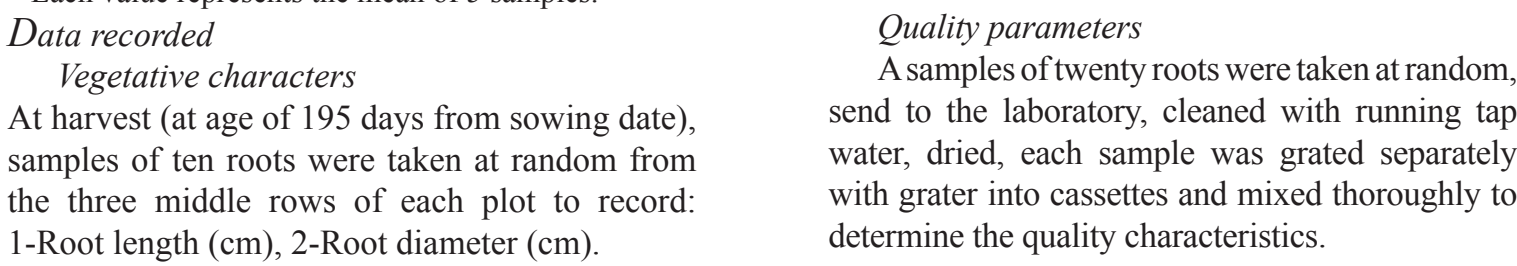 } \\
\hline
\end{tabular}


A-Physical properties: Sugar recovery \%, sugar loss percent and Quality index were calculated using the following equations according to Cooke \& Scott (1993):

1.Sugar recovery $\%=$ Pol. $\%-[0.29+0.343(\mathrm{~K}+$ $\mathrm{Na})+\mathrm{a}-\mathrm{N}(0.094)]$.

2. Sugar loss percent $=[0.29+0.343(\mathrm{~K}+\mathrm{Na})+$ a- N (0.094)].

where, $\mathrm{K}, \mathrm{Na}$ and $\mathrm{a}-\mathrm{N}$ determined as milliequivalent $/ 100 \mathrm{~g}$ beet.

3. Quality index $\%=$ Sugar recovery $\%$ x $100 \div$ Pol \%.

\section{B-Chemical composition:}

1. Polarization in sugar beet (Pol \%) was estimated in fresh samples of sugar beet roots, using saccharometer according to the method described in AOAC (2005).

2. Alpha amino nitrogen, sodium and potassium contentswere estimated according to the procedure of sugar company by Auto Analyzer. The results were calculated as milliequivalent per $100 \mathrm{~g}$ beet.

\section{Productivity traits}

1.Roots yield (ton /fad): At harvest (195 days after sowing) plants of sugar beet were taken from the three middle rows of each plot harvested to determine roots yield as ton/fad on fresh weight basis.

2.Recoverable sugar yield (ton/fad) was calculated from the following equation:

Recoverable sugar yield (ton $/$ fad $)=$ Roots yield (ton /fad) x Sugar recovery $\%$.

\section{Statistical analysis}

Data collected of each season were statistically analyzed according to line by Gomez \& Gomez (1984). Homogeneity of variance was examined before combined analysis. Differences among treatments were evaluated by the least significant difference test (LSD) at $5 \%$ significance level.

\section{Results and Discussion}

\section{Vegetative traits}

Yeasts are a poorly investigated group of microorganisms that represent an abundant and dependable source of bioactive and chemically novel compounds. The obtained results in this work (Table 2) reveal that the studied vegetative traits of sugar beet, i.e., root length and diameter $(\mathrm{cm})$, responded significantly to addition time of yeast during the two growing seasons and combined, except the $1^{\text {st }}$ season for root length $(\mathrm{cm})$, which didnot respond significantly. Combined analysis shows that adding yeast at age 140 days caused an increase in root length $(\mathrm{cm})$ by 2.61 and $2.44 \%$ as well as root diameter by $6.00 \%$ and $2.25 \%$ compared with addition time of yeast at ages 80 and 110 days from sowing, respectively. This finding might be due to overall enhancement of the plant nutrition, production of the phytohormones, cell division and elongation (Hashem et al., 2008). These data revealed that addition time of yeast had the higher effect on root diameter than root length. This might be due to an increase in the thickness of growth rings of sugar beet roots by increasing the diameter average of the cells (Cloete et al., 2009). The positive effect of yeasts on Chl. a and b is in consistence with the result obtained by Stino et al. (2009), who stated that the increase in Chl. a and b a consequent increase in total carbohydrates, because the yeast application could be have a role in cell division enhancement and cell elongation producing These findings are in the same trend with those obtained by Ferweez et al. (2011) and Agamy et al. (2013). In this respect, Shehata et al. (2012) mentioned that yeast is a source of phytohormones, minerals and stimulatory effect on division and enlargement of cells as well as protein and nucleic acids synthesis.

The results tabulated in Table 2 indicate that K-fertilizer level exhibited a significant effect on vegetative traits of sugar beet, i.e., root length and diameter $(\mathrm{cm})$ in the two growing seasons and combined. It was observed from combined analysis that applying $\mathrm{K}_{2} \mathrm{O}$ at 24 and $48 \mathrm{~kg} / \mathrm{fad}$ led to a significant increase in root length by 6.21 and $9.01 \%$ as well as root diameter 2.66 and $3.99 \%$ compared to the control (without applying $\mathrm{K}_{2} \mathrm{O}$ ), respectively. $\mathrm{K}$ is an essential element for plant growth with respect to its physiological and biochemical functions. It is necessary for activating starch synthetase enzyme (Fathy et al., 2009). The increase in root length and diameter of sugar beet as result of applying $\mathrm{K}_{2} \mathrm{O}$ at 48 $\mathrm{kg} / \mathrm{fad}$ was appreciable higher than $24 \mathrm{~kg} / \mathrm{fad}$. This increase might be mainly due to increasing photosynthesis products which migrate to storage sites in sugar beet roots. These findings are in the same trend with those recorded by Wang et al. (2013) who reported that K plays an essential role in enzyme activation, protein synthesis, photosynthesis, osmoregulation, stomatal movement, energy transfer, phloem transport, cation-anion balance, and stress resistance. 


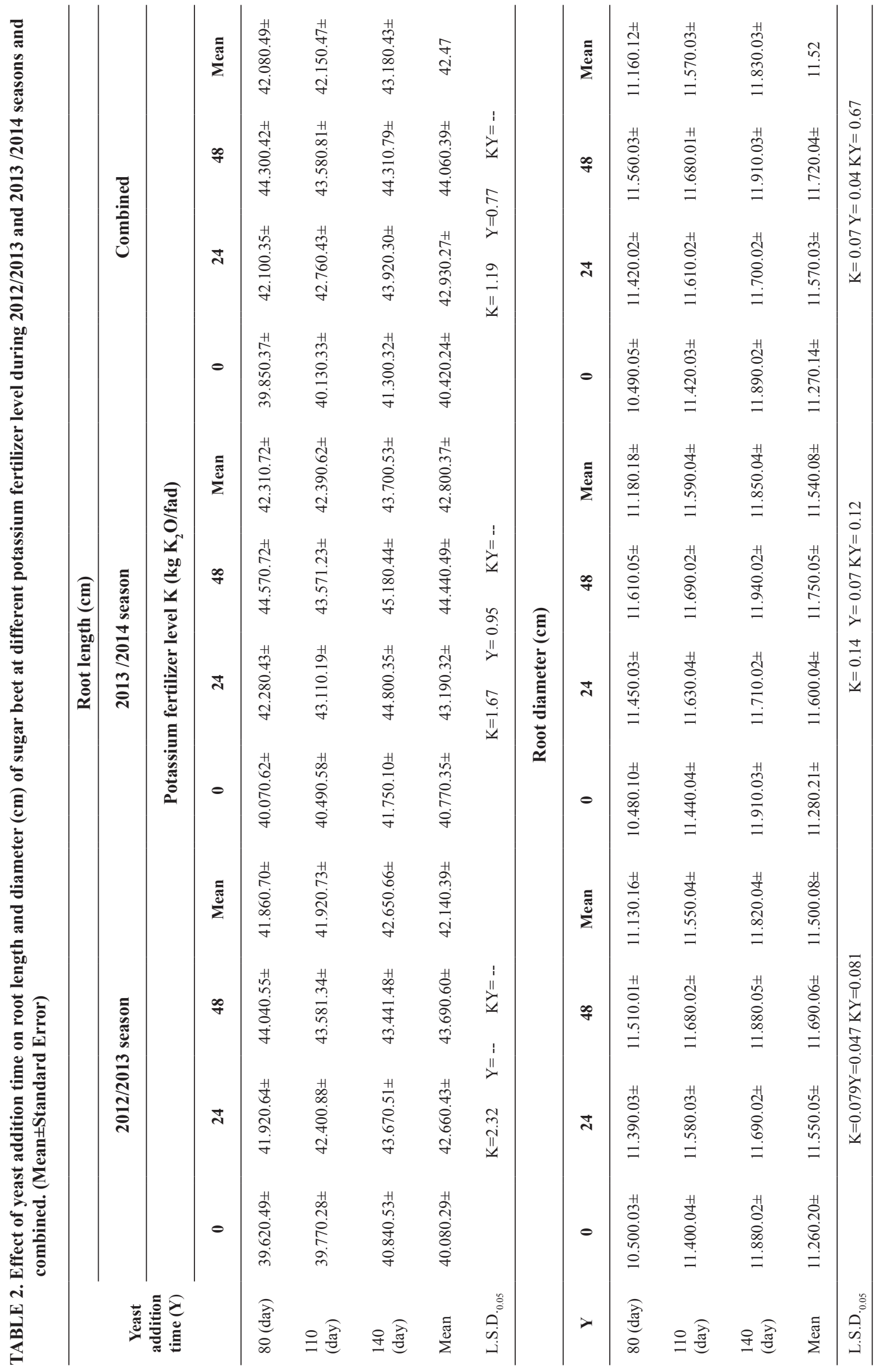


The interaction between addition time of yeast with K-fertilization level was significant on root diameter $(\mathrm{cm})$ in the two growing seasons and combined (Table 2). The highest values $(11.91 \mathrm{~cm})$ of root diameter was recorded with adding time of yeast at age 140 days and applying $48 \mathrm{~kg} \mathrm{~K}_{2} \mathrm{O} / \mathrm{fad}$, respectively. On the other hand, root length was not significantly affected by interaction between the studied factors.

\section{Physical properties of beet roots quality}

Addition time of yeast exhibited a significant effect on physical properties of beet roots, i.e., sugar recovery \% (SR\%), quality index \% (QZ\%) and sugar loss (SL\%) of sugar beet in both seasons and combined as shown in Table 3. It was revealed from combined analysis that adding yeast at age 80 days from sowing recorded an increase in SR\% by 11.70 and $15.81 \%$, QZ\% increased by 2.73 and $4.11 \%$ while, SL\% decreased by 6.55 and $12.03 \%$ over adding yeast at ages 110 and 140 days, respectively. This result might be due to that application of active bread yeast was very effective in releasing $\mathrm{CO}_{2}$, which reflected on improving net photosynthesis (Al-Falih, 2006), and adding yeast at age 80 days available the longest period than adding yeast at ages 110 and 140 days,for the sugar transport from the leaves to roots, consequently the highest increase in sucrose $\%$ or pol $\%$, of beet roots, consequently the increase in both SR\% and QZ\%. However, SL\% of beet roots with adding yeast at age 140 days was the highest than 80 and 110 days, respectively. This might be due to that the lowest increase in sucrose $\%$ or pol $\%$ of sugar beet juice was the lowest with adding yeast at age 140 days than 80 and 110 days (Table 4), respectively. The period shortage for the sugar transport from the leaves to the roots with adding yeast at age 140 days. These findings are in the same trend with those obtained by Ferweez et al. (2011) and Agamy et al. (2013).

Results obtained in this work (Table 3) reveal that potassium fertilization level had a significant effect on $\mathrm{SR} \%, \mathrm{QZ} \%$ and SL\% of sugar beet in both seasons and combined. It was demonstrated from combined analysis that adding $\mathrm{K}_{2} \mathrm{O}$ by 24 and $48 \mathrm{~kg} /$ fad led to an increasing in SR\% of sugar beet by 16.33 and $5.96 \%$, QZ\% of sugar beet increased by 2.76 and decreased by $0.47 \%$, while, SL $\%$ of sugar beet decreased by $1.88 \%$ and increased by $9.15 \%$ compared with control (zero $\mathrm{K}_{2} \mathrm{O} / \mathrm{fad}$ ), respectively. This result might be due to the increasing in soluble solutes, especially sucrose, in the juice of beet roots with adding $\mathrm{K}_{2} \mathrm{O}$, especially by $24 \mathrm{~kg} / \mathrm{fad}$, (Shalaby et al., 2002). These findings are in general line with those obtained by Ferweez \& Abo El.Wafa (2004).
It is observed from the results in Table 3 that the interaction between addition time of yeast and $\mathrm{K}$ fertilizer level with respect to SR\%, QZ\% and SL\% of sugar beet reached the significant level in both seasons and combined. It was showed from combined analysis that adding yeast at age 80 days from sowing with $24 \mathrm{~K}_{2} \mathrm{O} \mathrm{kg}$ /fad gave the highest values (16.27 and $86.99 \%$ ) for SR $\%$ and QZ\% of sugar beet and the lowest value (2.44\%) for SL \% of sugar beet. This is to be expected because there was a reverse relationship between sugar beet SR\% or QZ\% and SL\%.

\section{Chemical constituents of beet roots}

With regard to effect of addition time of yeast on the chemical constituents of beet roots, i.e., pol\% and impurities, such as alpha amino nitrogen $(\alpha-\mathrm{N})$, potassium $(\mathrm{K})$ and sodium $(\mathrm{Na})$ contents of sugar beet. Data given in Table 4 and Fig. 1 clarify that addition time of yeast had a significant effect on pol $\%, \alpha-\mathrm{N}, \mathrm{K}$ and $\mathrm{Na}$ contents of sugar beet in both seasons and combined. It was observed from combined analysis that adding yeast at age 80 days led to increasing in pol\% of sugar beet by 8.70 and $11.10 \%$ than adding yeast at 110 and 140 days from sowing, respectively. While, adding yeast at age 110 and 140 days from sowing led toincrease in $\alpha-\mathrm{N}$ content of sugar beet increased by 16.64 and 33.66 $\%$; K content of beet roots by 7.23 and $11.59 \%$ as well as $\mathrm{Na}$ content of beet roots by 5.30 and 14.45 $\%$ compared with adding yeast at age 80 days, respectively. This increment in $\alpha-\mathrm{N}, \mathrm{K}$ and Na contents of beet roots might be due to the availability of soil yeast to convert the unavailable forms of nutrient elements such $\mathrm{K}$ and $\mathrm{P}$ elements to available forms by generating of carbon dioxide from bio-fertilizers (Kurtzman \& Fell, 2005). They pointed out that role of $\mathrm{K}$ promotes carbohydrates translocation to roots, and cause the increase in pol $\%$ of beet roots, where $\mathrm{K}$ used as co-enzyme with phosphorase to form sucrose. Some soil yeasts are found to assimilate intermediates of lignin degradation, that is, ferulic acid, gallic acid, 4-hydroxybenzoic acid, protocatechuic acid and vanillic acid (Botha, 2011). We could state that production of such chemical compounds by the yeasts could serve as precursors or intermediates of beneficial compounds for the plants like growth hormones, fungicides, soil particles aggregators, or plants could assimilate them into valuable compounds. Hence, these compounds could directly or indirectly enhance the growth and the productivity of the sugar beet plants.Such data confirmed the previous reports of Ferweez et al. (2011) and Agamy et al. (2013) who showed that yeasts caused the increase in the sucrose content of beet roots. 


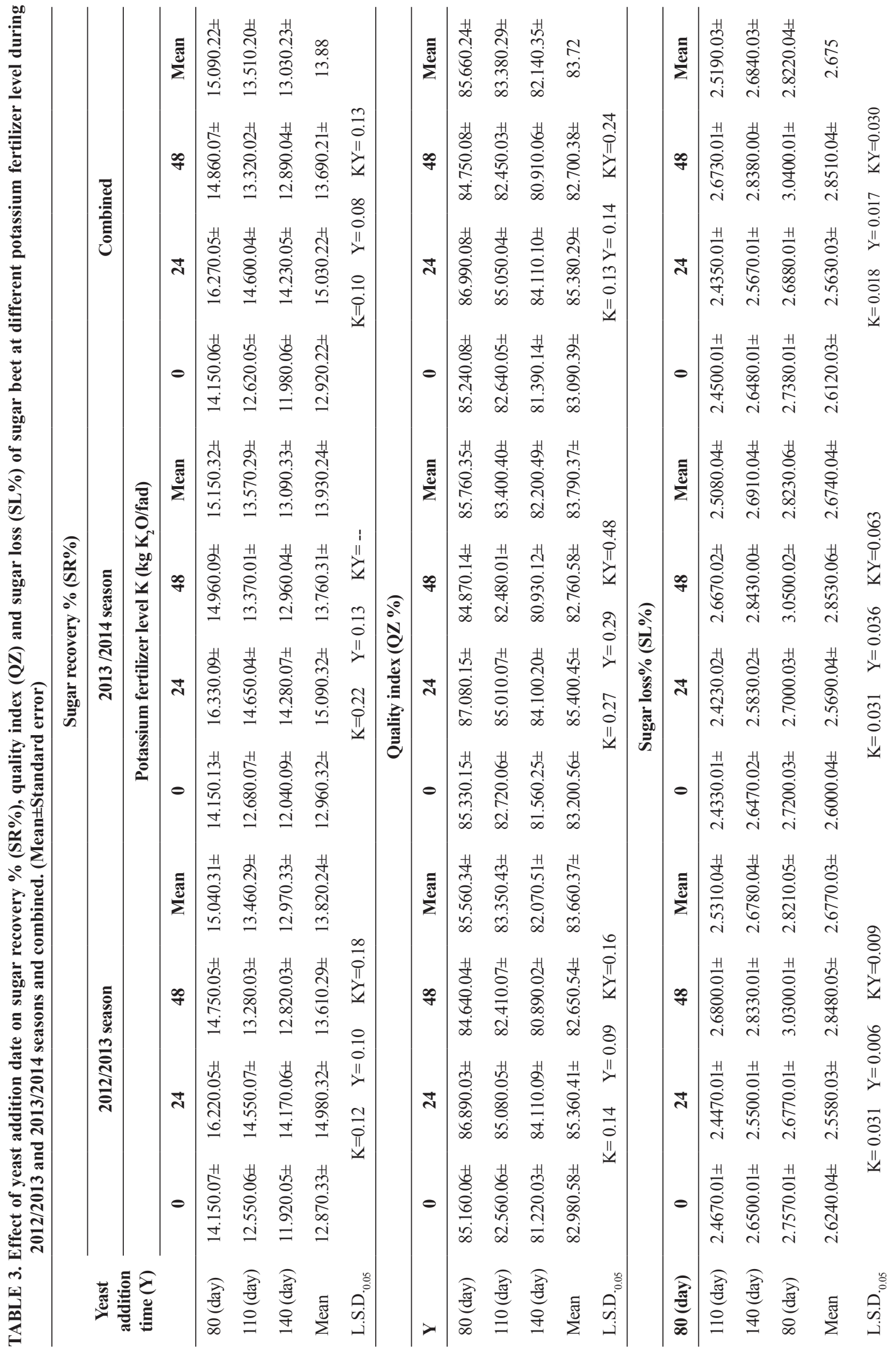




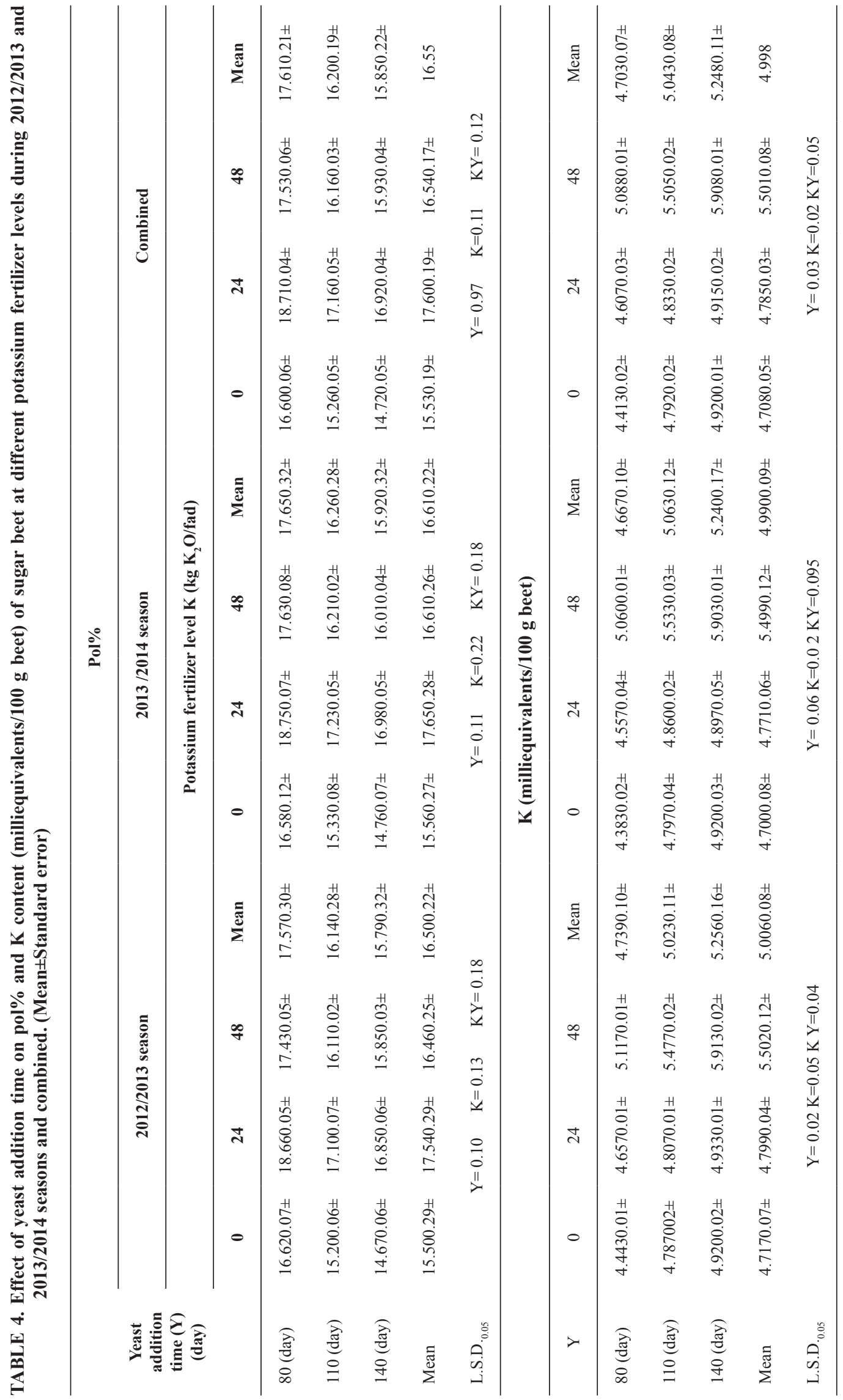

Egypt.J.Agron. Vol.40, No.1 (2018) 


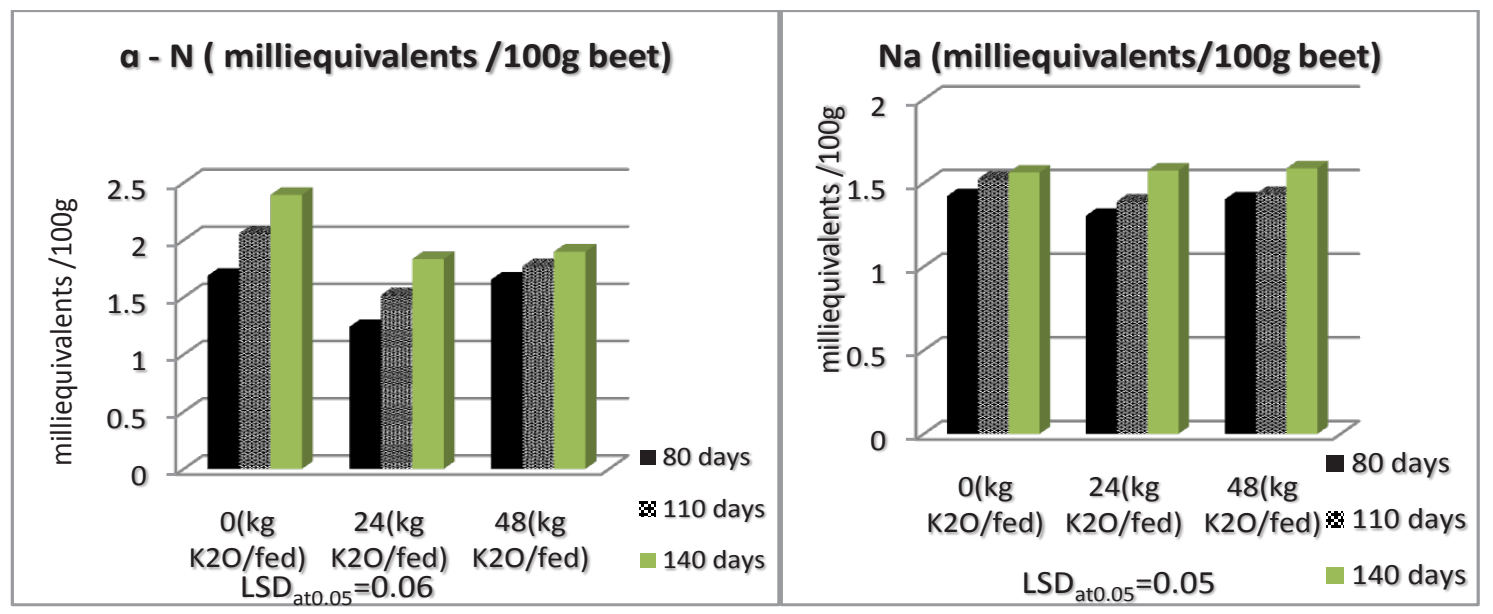

Fig. 1. Effect of yeast addition time on $\mathrm{a}-\mathrm{N}$ and $\mathrm{Na}$ content (milliequivalents/100g beet) of sugar beet at different potassium fertilizer level at combined 2012/2013 and 2013/2014 seasons.

The present results in Table 4 and Fig. 1 indicate that applying $\mathrm{K}_{2} \mathrm{O}$ exhibited a remarkable and significant effect on pol $\%, \alpha-\mathrm{N}, \mathrm{K}$ and $\mathrm{Na}$ contents of sugar beet in both seasons and combined, except the $2^{\text {nd }}$ season for Na content of beet roots not reached significant level. It was observed from combined analysis that there was an increase in pol $\%$ of sugar beet by 13.33 and $6.50 \%$ and $\mathrm{K}$ content of beet roots by 1.64 and $16.84 \%$ compared with applying $\mathrm{K}_{2} \mathrm{O}$ at 24 and $48 \mathrm{~kg} /$ fad over the control (zero $\mathrm{K}_{2} \mathrm{O} / \mathrm{fad}$ ), respectively. This increase might be due to the role of $\mathrm{K}$ which encourage carbohydrates translocation to store in roots, then transformed to sucrose must be considered the increase in pol $\%$ of beet roots, where potassium used as Co-Enzyme with phosphorase to form sucrose (El. Harriri \& Gobarh, 2001 and Shalaby et al., 2002 ). While, $\alpha-\mathrm{N}$ content of sugar beet was decreased by 33.81 and $15.40 \%$ and $\mathrm{Na}$ content of sugar beet by 5.62 and $1.83 \%$ compared with applying $\mathrm{K}_{2} \mathrm{O}$ at 24 and $48 \mathrm{~kg} / \mathrm{fad}$ over the control (zero $\mathrm{K}_{2} \mathrm{O} / \mathrm{fad}$ ), respectively. This decrease might be due to the increase in pol\% of sugar beet. Such results are in the same line with those of Neseim et al. (2014).

Significant interactionswere recorded between addition time of yeast and potassium fertilization level on chemical constituents, i.e., pol $\%, \alpha-\mathrm{N}, \mathrm{K}$ and $\mathrm{Na}$ contents of sugar of beet roots during the two growing seasons and combined as shown in Table 4 and Fig.1. The maximum value (18.71\%) of pol $\%$ of sugar beet was obtained with adding yeast at age 80 days from sowing and $24 \mathrm{~kg} \mathrm{~K}_{2} \mathrm{O} / \mathrm{fad}$, which achieved the best use of yeast and potassium fertilization. This result is in agreement with those recorded by Neseim et al. (2014) who found that $\mathrm{K}$ in combination with yeast foliar spray increased pol\% of sugar beet and reduced in sodium and $\alpha$ - amino $\mathrm{N}$ contents of sugar beet crop.

\section{The productivity traits}

The data obtained in this work (Table 5) reveal that the studied productivity traits, root yield and recoverable sugar yield (ton/fad) of sugar beet responded significantly to addition time of yeast during the two growing seasons and combined. It could be noted from combined analysis that adding yeast at age 140 days caused an increase in root weight by 15.62 and $10.01 \%$ compared with addition time of yeast at ages 80 and 110 days from sowing, respectively. While, recovserable sugar yield of sugar beet with adding yeast at age 80 days increased by 6.46 and $0.17 \%$ compared with addition time of yeast at ages 110 and 140 days from sowing, respectively. These results might be attributed to soil fertilized by yeast shown improvement in specific gravity (lower bulk density), which led to an increase in root length and diameter of sugar beet, consequently adding late yeast at 140 days led to an encourage the vegetative growth and increase in root yield (ton/fad) of sugar beet compared with the other (Mirabal Alonso et al., 2008). Here also, macro and micronutrients content, growth regulators and vitamins of yeast added at late age (140 days) can play a very significant role in making available nutrient elements for plants and stimulate the plant to build up dry matter (Hesham \& Mohamed, 2011). They clarified that bread yeast (Saccharomyces cervisiae) as a natural bio-stimulant appeared to induce an astonished influence on growth and yield of many crops, since it has various basic functions, i.e., $\mathrm{CO}_{2}$ production as well as formation of alcohol, acids and esters. Such results are in the same line with those found by Ferweez et al. (2011) who revealed that adding yeast had a significant effect on root and recoverable sugar yield (ton/fad) of sugar beet. 


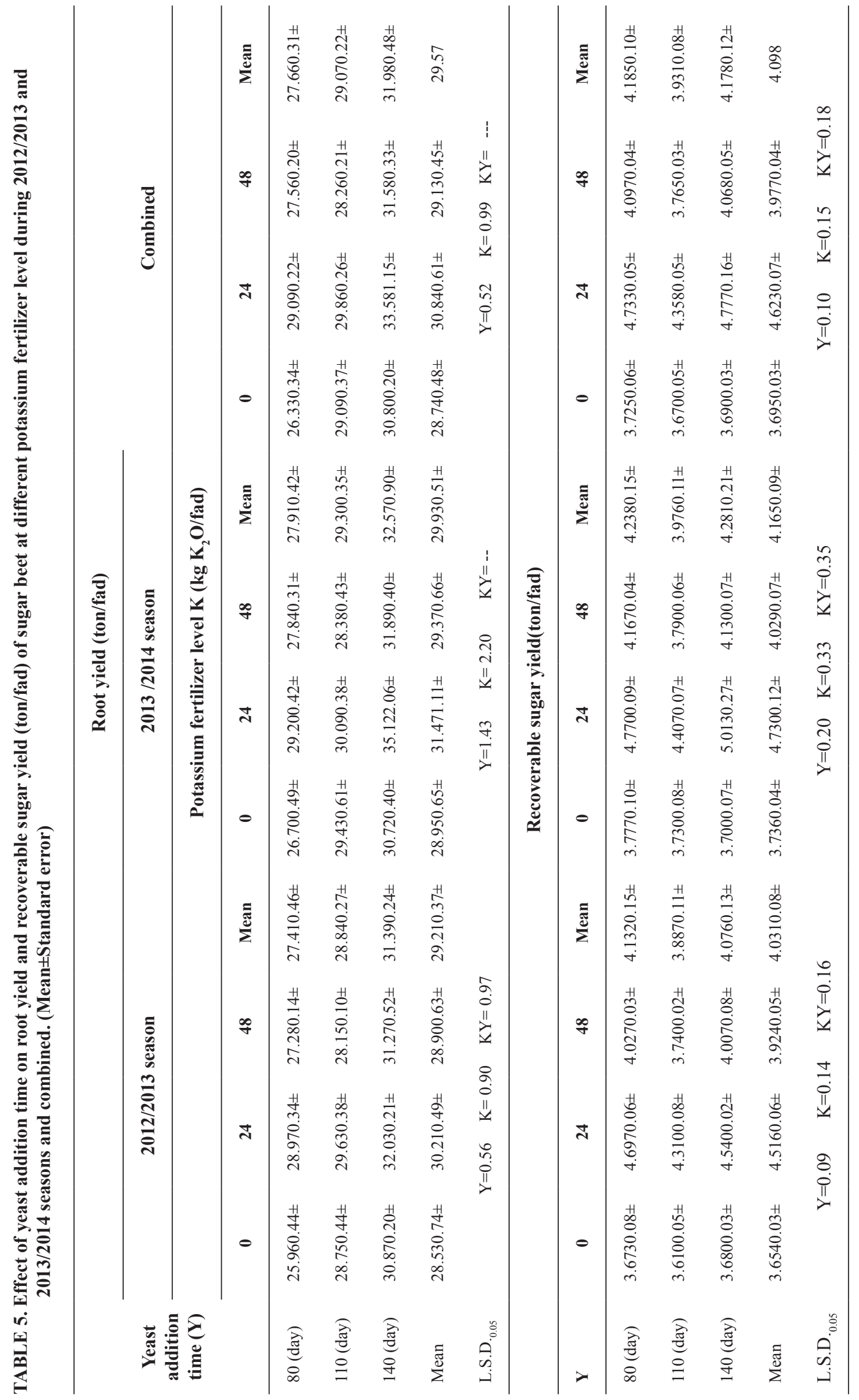

Egypt.J.Agron. Vol.40, No.1 (2018) 
Data in Table 5 clarified that applying $\mathrm{K}_{2} \mathrm{O}$ exhibited a remarkable and significant effect on root yield and recoverable sugar yield (ton/fad) of sugar beet in both seasons and combined. It was observed from combined analysis that there was an increase in root yield of sugar beet by 7.31 and $1.36 \%$ and recoverable sugar yield of beet roots by 25.12 and $7.63 \%$ with applying $\mathrm{K}_{2} \mathrm{O}$ at 24 and $48 \mathrm{~kg} / \mathrm{fad}$ over the control (zero $\mathrm{K}_{2} \mathrm{O}$ / fad), respectively. The increase in root yield of sugar beet might be expected due to the increase in both root length and diameter of sugar beet (Table 2). While, the increase in recoverable sugar yield might be due to the increase in both root yield and pol\% of sugar beet. The maximum value (4.73 and 4.78 tons/ fad) in recoverable sugar yield of sugar beet was achieved by applying $\mathrm{K}_{2} \mathrm{O}$ at $24 \mathrm{~kg} / \mathrm{fad}$ than $48 \mathrm{~kg} / \mathrm{fad}$. This result might be explained as the high levels of K-fertilizer led to an increase of the impurities in juice of beet roots such as $\mathrm{K}$ milliequivalent/100 gm beet, and consequently reduced sugar recovery $\%$ of sugar beet. Our findings are in good accordance with those published by Shahidi \& Khalafi (2010); Mehrandish et al. (2012) and Salami \& Saadat (2013). They showed that the application of $\mathrm{K}$ increased root yield, sugar yield, sugar content and other qualitative characteristics of sugar beet.

Significant interactions were recorded between addition time of yeast and potassium fertilization level on root yield and recoverable sugar yield of beet roots during the two growing seasons and combined as shown in Table 5 . Therefore, the highest value (33.58 ton/fad) for root yield of sugar beet was obtained with adding yeast at age 140 days from sowing and $24 \mathrm{~kg} \mathrm{~K}_{2} \mathrm{O} / \mathrm{fad}$. While, the highest values (4.73 and $4.78 \mathrm{ton} / \mathrm{fad}$ ) for recoverable sugar yield of sugar beet was recorded with adding yeast at ages 80 and 140 days from sowing with $24 \mathrm{~kg} \mathrm{~K}_{2} \mathrm{O} / \mathrm{fad}$, respectively. This means that adding yeast at 80 days from sowing together with $24 \mathrm{~kg} \mathrm{~K}_{2} \mathrm{O} / \mathrm{fad}$ achieved the best use of yeast and potassium fertilization. This result is agreement with those recorded by Neseim et al. (2014) who found that $\mathrm{K}$ in combination with yeast foliar spray increased root and white sugar yield of sugar beet.

Profitability of sugar beet with adding yeast at different levels ofK-fertilizer
Concerning addition time of yeast effect, it is noticed from the results in Table 6 that adding yeast at age 80 days markedly increased the total return per fad by 27.64 and $26.85 \%$ and net profit by 60.80 and $58.64 \%$ as well as sugar yield in ton/1000 $\mathrm{m}^{3}$ by 7.14 and $0.84 \%$ compared with applying yeast at ages 110 and 140 days, respectively. While, root yield in ton $/ 1000 \mathrm{~m}^{3}$ increased by 5.19 and $15.70 \%$ with applying yeast at ages 110 and 140 days compared with adding yeast at age 80 days from sowing date, respectively.

Data given in Table 6 clarified that the total return per fad was markedly increased by 20.85 and $15.91 \%$ and net profit by 224.88 and $82.78 \%$ with applying $\mathrm{K}_{2} \mathrm{O}$ at 24 and 48 $\mathrm{kg} /$ fad compared with control, respectively. In addition, root yield in ton $/ 1000 \mathrm{~m}^{3}$ increased by 7.30 and $1.34 \%$ and sugar yield (in ton) $/ 1000 \mathrm{~m}^{3}$ by 24.53 and $7.55 \%$ with applying $\mathrm{K}_{2} \mathrm{O}$ at 24 and $48 \mathrm{~kg} / \mathrm{fad}$ over the control, respectively.

\section{Conclusion}

A good understanding of the role of soil yeasts in the rhizosphere holds a key to future sustainable agricultural practices. In Egypt, increasing the sugar production from sugar beet by improving the quality of beet roots should reduce the vast gap between sugar production and consumption. In general, it can be concluded from the results that applying yeast at age 80 days from sowing with $24 \mathrm{~kg} \mathrm{~K} \mathrm{~K}_{2} \mathrm{O} / \mathrm{fad}$ could be recommended because it achieved the highest values of SR \% (16.27\%), QZ (86.99\%) and pol\% (18.71), while it contained the lowest values of SL\% (2.44\%); a-N (1.24 milliequivalent/100g) and $\mathrm{Na}(1.31$ milliequivalent $/ 100 \mathrm{~g})$ contents. Also applying yeast at age 80 or 140 days from sowing with $24 \mathrm{~kg} \mathrm{~K}_{2} \mathrm{O} / \mathrm{fad}$ had the highest value of recoverable sugar yield (4.73 and $4.78 \mathrm{ton} / \mathrm{fad})$, respectively.

Acknowledgment: First author gratefully acknowledges Sugar Crops Res. Dept., Mallawi Agric. Res. Station, Minia Governorate, Agricultural Research Center, Ministry of Agric. \& Land Rec., Egypt, for their cooperation, assistance, financial support and all facilities offered to me throughout carrying out this study and to overcome all the obstacles to bring this work into light. 
Table 6 . Some economics of sugar beet productivity per faddan with yeast application and three $\mathrm{K}$ fertilizer levels.

\begin{tabular}{|c|c|c|c|c|c|c|}
\hline \multirow{2}{*}{ Items } & \multicolumn{3}{|c|}{ Addition time of yeast } & \multicolumn{3}{|c|}{ PotassiumFertilizer $\left(\mathrm{K}_{2} \mathrm{O} / \mathrm{fad}\right)$} \\
\hline & 80 days & 110 days & 140 days & 0 kg & $24 \mathrm{~kg}$ & $48 \mathrm{~kg}$ \\
\hline \multicolumn{7}{|l|}{ Costs (L.E.) $* *$} \\
\hline \multicolumn{7}{|l|}{ Variable costs**: } \\
\hline i.e. irrig., ferti. etc & & 3000 & & 3000 & 3300 & 3600 \\
\hline \multicolumn{7}{|l|}{ Fixed costs: $* *$} \\
\hline Overhead & \multicolumn{6}{|c|}{200} \\
\hline Rental value & \multicolumn{6}{|c|}{3000} \\
\hline Total costs: & & 6200 & & 6200 & 6500 & 6800 \\
\hline \multicolumn{7}{|c|}{ Productivity (in ton): } \\
\hline Root yield/fad & 27.66 & 29.07 & 31.98 & 28.74 & 30.84 & 29.13 \\
\hline Sugar/fad & 4.185 & 3.931 & 4.178 & 3.695 & 4.623 & 3.977 \\
\hline \multicolumn{7}{|c|}{ Prices (L.E./ton) **: } \\
\hline Roots & 550 & 410 & 375 & 335 & 550 & 440 \\
\hline \multicolumn{7}{|c|}{ Total Return (L.E./fad): } \\
\hline Root yield & 15213 & 11918.7 & 11992.5 & 9627.9 & 16962 & 12817.2 \\
\hline Net profit (L.E.) & 8713 & 5418.7 & 5492.5 & 3127.9 & 10162 & 5717.2 \\
\hline \multirow[t]{2}{*}{ Return-cost ratio } & 2.34 & 1.83 & 1.85 & 1.48 & 2.49 & 1.81 \\
\hline & \multicolumn{2}{|c|}{ Quantity of water $\mathrm{m}^{3} /$ fad: } & \multicolumn{4}{|c|}{3500.00} \\
\hline Yield(ton) $/ 1000 \mathrm{~m}^{3}$ & 7.90 & 8.31 & 9.14 & 8.21 & 8.81 & 8.32 \\
\hline Sugar(ton) $/ 1000 \mathrm{~m}^{3}$ & 1.20 & 1.12 & 1.19 & 1.06 & 1.32 & 1.14 \\
\hline Net-profit(L.E.) $/ 1000 \mathrm{~m}^{3}$ & 2489.43 & 1576.77 & 1569.29 & 893.69 & 2903.43 & 1633.49 \\
\hline
\end{tabular}

According to Garg \& Azad (1975), ** Sources of CCSC (2017), * L.E.=Egyptian pound

\section{$\underline{\text { References }}$}

A.O.A.C. (2005) Association of Official Analytical Chemists. "Official Methods of Analysis", $18^{\text {th }}$ ed., AOAC International, Washington, DC.

Abdelaal, Kh.A.A. (2015) Pivotal role of bio and mineral fertilizer combinations on morphological, anatomicaland yield characters of sugar beet plant (Beta vulgaris L.). Middle East Journal of Agriculture Research, 4(4) Oct.-Dec. 717-734.

Abido, W.A.E., Ibrahim, M.E.M. and El.Zeny, Maha M. (2015) Growth , productivity and quality of sugar beet as affected by antioxidants foliar application and potassium fertilizer top dressing. Asian Journal of Crop Science, 7(2), 113-127.

Agamy, R., Hashem, M. and Alamr, S. (2013) Effect of soil amendment with yeasts as bio-fertilizers on the growth and productivity of sugar beet. Afr. J. Agr. Res. 7(49), 6613-6623.

Al-Falih, A.M. (2006) Nitrogen transformation in vitro by some soil yeasts. Saudi. J. Biol. Sci. 13(2), 135-140.
Boraste, A., Vamsi, K.K., Jhadav, A., Khairnar, Y., Gupta, N., Trivedi, S., Patil, P., Gupta, G.,Gupta, M., Mujapara, A.K. and Joshi, B. (2009) Bio-fertilizers: A novel tool for agriculture. Int. J. Microbiol. Res. 1(2), 23-31.

Botha, A. (2011) The importance and ecology of yeasts in soil. Soil Biol. Biochem. 43,1-8.

Cakmak, I.(2005) The role of potassium in alleviating detrimental effects of abiotic stresses in plants. Journal of Plant Nutrition and Soil Science, 168, 521-530.

CCSC (2017) Central Council for Sugar Crops. Annual Report, Ministry of Agriculture, Egypt. (In Arabic).

Cloete, K.J., Valentine, A.J., Stander, M.A., Blomerus, L.M. and Botha, A. (2009) Evidence of symbiosis between the soil yeast Cryptococcus laurentii and a sclerophyllous medicinal shrub. Agathosma betulina (Berg.) Pillans. Microb. Ecol. 57, 624-632.

Cooke, D.A. and Scott, R.K. (1993) "The Sugar Beet Crop". Science Practice published by Chapman \& Hall, London 
El. Harriri, D.M. and Gobarh, M.E. (2001) Response of growth, yield and quality of sugar beet to nitrogen and potassium fertilizers under newly reclaimed sandy soil. J. Agric. Sci. Mansoura Univ. 26(10), 5895-5907.

Fathy, M.F., Abd El-motagally, A. and Attia, K.K. (2009) Response of sugar beet plants to nitrogen and potassium fertilization in a sandy calcareous soil. Int. J. Agric. Biol. 11, 695-700.

Ferweez, H. and AboEl.Wafa, A.M. (2004) Enhancing the productivity, quality and profitability of sugar beet using optimal levels and addition time of potassium fertilizer under middle Egypt conditions. Assuit J. Agric. Sci. 35(3), 108-127.

Ferweez, H.M., Khalifa, Y.A.M. and Mohamed, Kh.El. Sh. (2011) Response of sugar beet (Beta vulgaris L.) yield and quality to soil application of yeast at different nitrogen fertilizer levels. Minia J. Agric. Res. Develop. 31(3), 19-38.

Garg J. S. and Azad M.P. (1975): Economics of a crossboard cow, Indian journal Agricultural economics, Vol. XXX No. 3 P.P-149-150.

Gomez, K.A. and Gomez, A.A. (1984) "Statistical Procedures for Agricultural Research". $2^{\text {nd }}$ ed. John Willey and Sons, New York, pp.680.

Hesham, A.L. and Mohamed, H. (2011) Molecular genetic identification of yeast strains isolated from Egyptian soils for solubilization of inorganic phosphates and growth promotion of corn plants. J. Microbiol. Biotechnol. 21, 55-61.

Hashem, M., Omran, Y.M. and Sallam, Nashwa M. (2008) Efficacy of yeasts in the management of root-knot nematode (Meloidogyne incognita) in flame seedless grape vines and the consequent on the productivity of the vines. Biocontrol Science and Technology, 18(4), 357-375.

Ibrahim, M.M., Khalifa, M.R., Koriem, M.A., Zein, F.I. and Omer, E.H. (2002) Yield and quality of sugar beet crop as affected by mid to late season drought and potassium fertilization at North Nile Delta. Egypt. J. Soil Sci. 42(1), 87-102.

Jackson, M. L. (1967) "Soil Chemical Analysis". Prentice - Hall, Inc, Englewood, Cliffs. NJ, USA.

Kurtzman, C.P. and Fell, J.W. (2005) Biodiversity and Ecophysiology of Yeasts. In: "The Yeast Handbook", Gabor, P., de la Rosa, C.L., (Ed.), pp. 11-30. Berlin, Springer.

Marschner, S. (2012) "Mineral Nutrition of Higher Plants", $3^{\text {rd }}$ ed.; pp. 178-189. Academic Press: London, UK.
Mehrandish, M., Moeini, M.M. and Armin, M. (2012) Sugar beet (Beta vulgaris L.) response to potassium application under full and deficit irrigation. Euro. J. Exp. Bio. 2(6), 2113-2119. www.pelagiaresearchlibrary.com.

Mirabal, Alonso L., Kleiner, D. and Ortega, E. (2008) Spores of the mycorrhizal fungus Glomusmosseae host yeasts that solubilize phosphate and accumulate polyphosphates. Mycorrhiza, 18, 197-204.

Nagodawithana, W.T. (1991) "Yeast Technology". Universal foods cooperation Milwauke, Wisconsin. Published by Van Nostrand, New York.

Neseim, M.R., Amin, A.Y. and El-Mohammady, M.M.S. (2014) Effect of potassium applied with foliar spray of yeast on sugar beet growth and yield under drought stress. Gl. Adv. Res.J. Agric.Sci. 3(8), 211-222.

Oliver, R. Khama, Cedric, K. and Nelson, L.E. (2013) Effect of soil adjustment with yeasts as biofertilizers on the growth and yield of sugar beet. International Journal of Manures and Fertilizers, 2(11), 424-433

Omran, Y.A. (2000) Studies on histo-physiological effect of hydrogen cyanamide (Dormex) and yeast application on bud fertility, vegetative growth and yield of "Roumi Red"' grape cultivar. Ph.D. Thesis, Fac. Agric., Assiut Univ., Egypt.

Pettigrew,W.T. (2008) Potassium influences on yield and quality production for maize, wheat, soybean and cotton. Physiol. Plantarum, 133, 670-681.

Salami, M. and Saadat, S. (2013) Study of potassium and nitrogen fertilizer levels on the yield of sugar beet in jolge cultivar. Journal of Novel Applied Sciences, 2 -4/ 94-100.

Shahidi, A.E. and Khalafi, K. (2010) Yield of seven sugar beet varieties under different levels of nitrogen in dry region of Ardebil. J. Nov. Appl. Sci. 47, 231-241.

Shalaby, M.T., Doma, M.B., Abd-El.Latief, F.A. and Sadik, S.M.E. (2002) Agricultural, chemical and technological studies on sugar beet 1- Effect of potassium application on yield,chemical constituents and juice quality characteristics of sugar beet. J. Agric. Sci. MansouraUniv. 27(11), 7503-7512.

Shehata, S.A., Fawzy, Z.F. and El-ramady, H.R. (2012) Response of cucumber plants to foliar application of chitosan and yeast under greenhouse conditions. Australian Journal of Basic and Applied Sciences, 6(4), 63-71. 
Stino, R.G., Mohsen, A.T., Maksouds, M.A., Abd El-Migeed, M.M.M., Gomaa, A.M. and Ibrahim, A.Y.(2009). Bioorganic fertilization and its Impact on Apricot young trees in newly reclaimed soil. American- Eura. J.Agric. Environ. Sci. 6(1), 62-69.

Wang, M., Zheng, Q., Shen, Q. and Shiwei Guo (2013) The critical role of potassium in plant stress response. Int. J. Mol. Sci. 14, 7370-7390.

Warring, P.E. and Phillips I.D.G. (1973) "The Control of Growth and Differentiation in Plants". E.L.B.S. Ed., Pub by Pergamon Press Ltd. VK.

(Received 20 / $11 / 2017$; accepted 23 / 1 / 2018 )

\section{زيادة ناتج، جودة وربحية بنجر السكر باستخدام ميعاد إضافة الخميرة ومستوى السماد

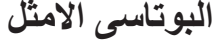

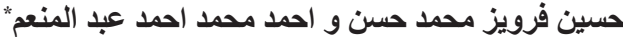

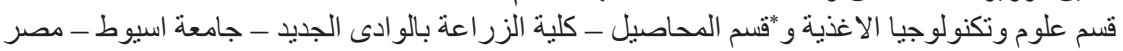

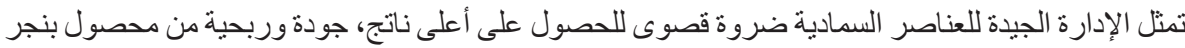

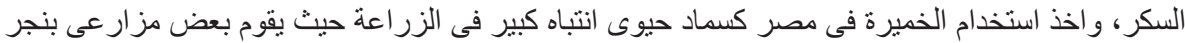

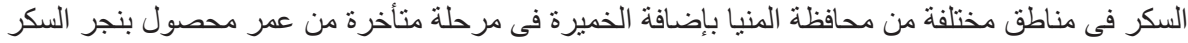

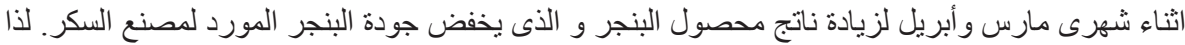

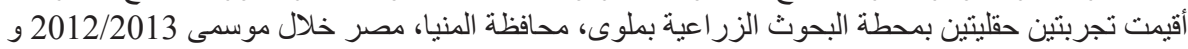

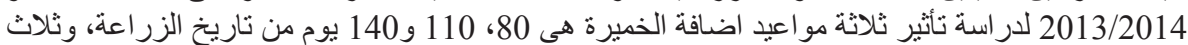

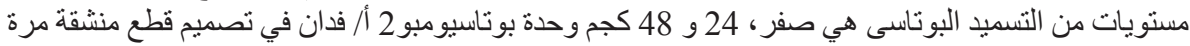

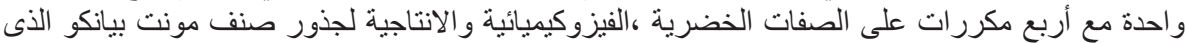
زرع في كلا الموسمين.

أوضحت النتائج المتحصل عليها:

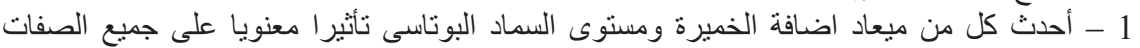

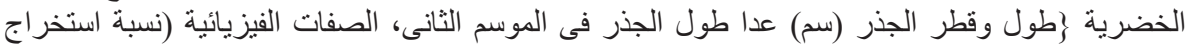

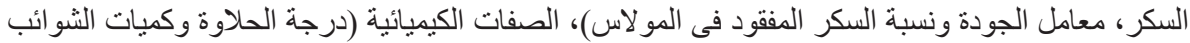

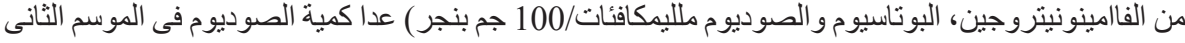

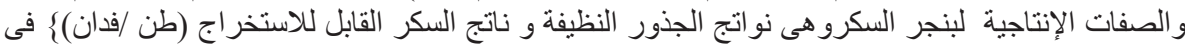

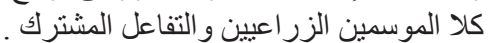

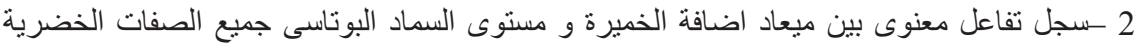

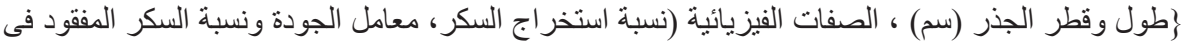

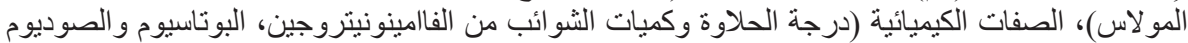

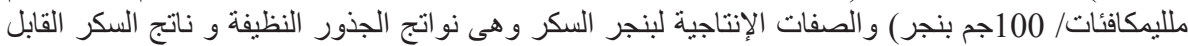

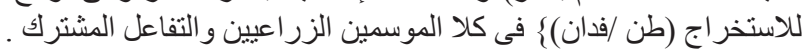

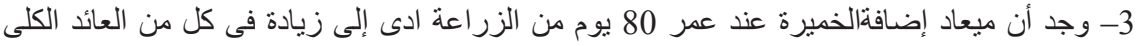

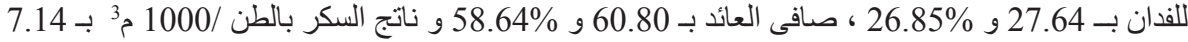

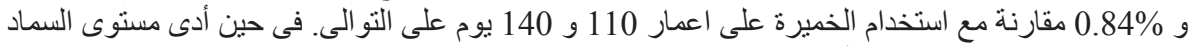

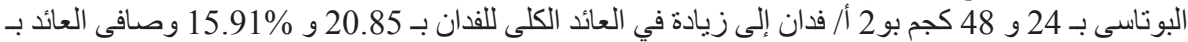

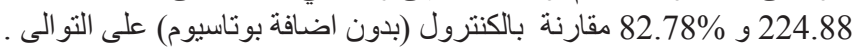

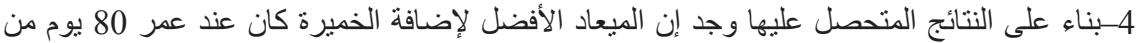

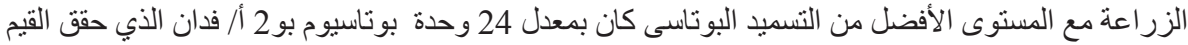

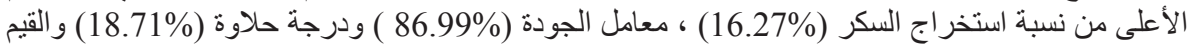

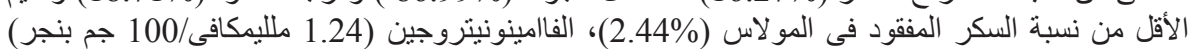

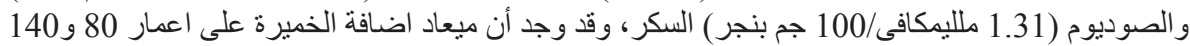

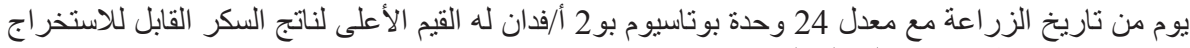

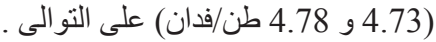

